\title{
A water-covered waste dump in an arid climate? A remediation concept for Brukunga Mine
}

\author{
D. Brett GHD Pty Ltd, Australia
}

M. O'Kane O'Kane Consultants Inc., Canada

P. Scott EES Pty Ltd, Australia

J.R. Taylor Earth Systems, Australia

M. McLeary Primary Industry and Resources South Australia, Australia

D.J. Williams Golder Geomechanics Centre, The University of Queensland, Australia

\begin{abstract}
The Brukunga Mine in the Adelaide Hills, $40 \mathrm{~km}$ east of the city, was a source of pyrite for fertiliser manufacture during the mid twentieth century. The legacy is an ongoing source of acid and metalliferous drainage $(A M D)$ requiring continuous collection, treatment with lime and disposal of sludge. The sources of AMD include a tailings storage facility, waste rock dumps and the exposed mine highwall.

The site is currently being managed by Primary Industry and Resources, South Australia (PIRSA), which initiated a study to review options for remediation of the site using a Technical Advisory Group (TAG) of specialist consultants. The overall process is described in a companion paper (Scott et al., 2011) at this conference and in more detail by McCleary (McCleary, 2009). The TAG's recommended solution comprised remixing the wastes and constructing a new disposal structure allowing continual saturation of the co-disposed material. Studies, including field trials of mixed tailings and waste rock to determine geotechnical properties, demonstrated that this can be achieved despite the relatively dry climate of the site.

The paper describes the development of the saturated dump concept, including discussion of geotechnical investigations, hydrogeological studies, water balance and both 2-D and 3-D hydrologic modelling. The water balance is achieved by minimising open water exposure while a permeable layer incorporated within the waste cover allows capture and distribution of recharge water from local streams. Saturation is maintained due to the relatively low permeability of the mixed waste material and the low water losses, even during prolonged dry periods. The critical aspect of the study was confirmation that there was a low risk of saturation levels within the co-disposed waste dropping sufficiently to allow oxidation to take place.
\end{abstract}

\section{Introduction}

This paper describes the evaluation of a saturated, co-disposed waste storage to allow remediation of historic mine wastes at the former Brukunga Mine site, located in the Adelaide Hills, $40 \mathrm{~km}$ east of Adelaide in South Australia. Approximately $8 \mathrm{Mt}$ of waste rock and $3.5 \mathrm{Mt}$ of tailings were produced during the operation of the mine, with oxidation of the waste material resulting in acid and metalliferous drainage (AMD) with $\mathrm{pH}<3$, elevated concentrations of sulphate and dissolved metals, emanating from the site as seepage and runoff.

A hydrated lime-based water treatment plant was commissioned at Brukunga in September 1980 to treat the AMD. This was initially targeted at treating the then most obvious source of acidic seepage from the tailings dam, but AMD is now also collected from the waste rock dumps, mine benches, and the exposed orebody.

The site has been managed by Primary Industries and Resources South Australia (PIRSA) since 1998. In 2001, funding was provided for implementation of a remediation programme involving 3 stages: (i) diverting Dawesley Creek in an attempt to contain AMD on the mine site; (ii) increasing the peak Water Treatment Plant (WTP) capacity by $100 \%$; and (iii) decreasing generation of acidic seepage by relocating and capping the waste rock dumps. The diversion drain was constructed in June 2003 and the WTP has been upgraded to 
a high density sludge operation. A review of the original strategy was undertaken in 2007 prior to proceeding with Stage 3. This review focussed on the feasibility of implementing a technical solution to achieve full remediation of the site. The Brukunga Remediation Project - Technical Advisory Group (TAG) was formed to assist PIRSA in achieving this. The purpose of the TAG has been to recommend to PIRSA a "walk-away" remediation solution, defined as needing no ongoing active water treatment, no further intervention and minimal ongoing maintenance.

Fifteen remediation options were considered by the TAG, including reshaping and stabilising waste storages by minimal earthworks and applying store and release covers comprising either selected clean wastes or imported materials; and relocation of wastes on-site by co-disposing and compacting in shaped dumps that could be kept saturated by local runoff. The TAG recommended that saturation of co-disposed wastes offered the lowest risk, most cost-effective and most achievable strategy for a walk-away remediation (TAG, 2008). The successful implementation of this option depends on sourcing sufficient suitable materials for the construction of containment walls, placement, compaction and progressive neutralisation of the co-disposed wastes and permanent maintenance of saturated conditions.

The TAG advised that, in the absence of a walk-away remediation solution, ongoing water treatment is likely to be required in perpetuity. Apart from the ongoing cost of water treatment, an ever-increasing volume of treatment sludge would have to be stored. Importantly, the conventional store and release capping option was found to be unlikely to reduce seepage volume or improve water quality sufficiently to eliminate the need for treatment.

The final concept required that the majority of waste rock and tailings to be co-disposed by mixing and compacting them in areas where local stream flow can be diverted to maintain saturation. Crushed limestone would be added to the co-disposed wastes to neutralise stored oxidation products. The co-disposed waste would be placed behind containments comprising embankments of clay and rock with appropriate foundation preparation to ensure minimisation of seepage from the saturated wastes placed upstream. This would include removal of fractured rock from the foundation and cement grouting of permeable rock features.

The co-disposed wastes would be covered with a horizontal layer of permeable crushed rock overlain by a soil cover suitable for vegetation growth, with recreated creeks over the final surface, able to feed water into the permeable rock layer to distribute water to the underlying wastes to maintain them in a saturated condition. The resulting landform would be landscaped and revegetated, with Dawesley Creek and other watercourses reinstated. It is envisioned that the landscape would include wetlands and natural meandering creek lines, with a range of native vegetation.

The key to the success of the proposal is the maintenance of saturated conditions within the waste under the most extreme environmental conditions.

\section{Site description}

The site covers an area of approximately 136 ha, comprising the mine void, waste rock stockpiles and a tailings storage facility (TSF) as shown in Figure 1. The surrounding terrain comprises rounded hills, mostly cleared for pasture. The topography reflects the underlying geological structure, with ridges running northsouth, parallel with the strike of the steeply-dipping foliation/cleavage of the bedrock (SKM, 2009).

The main surface drainage feature is Dawesley Creek, which extends from $5.5 \mathrm{~km}$ north of Brukunga, to $15 \mathrm{~km}$ south of the mine where it joins Mt Barker Creek, which in turn feeds into the Bremer River.

The conceptual aquifer model for the Mount Lofty Ranges and also, by direct analogy, the Brukunga region consists of a densely fractured, weathered, upper zone, clay saprolite (0 to $20 \mathrm{~m}$ depth, but typically much shallower at Brukunga), a less fractured transitional zone (20 to $40 \mathrm{~m}$ depth) and a broadly fractured lower zone (>40 m depth). With increasing depth there is a trend of decreasing fracture density based upon a reduction in the number of joint sets against a persistent background of dense bedding planes (TAG, 2009). Other than narrow, thin deposits of alluvium along major drainage lines, the main regional aquifer is within the fractured bedrock.

A conceptual geological and hydrogeological model of the site is presented in Figure 2 (TAG, 2009). 


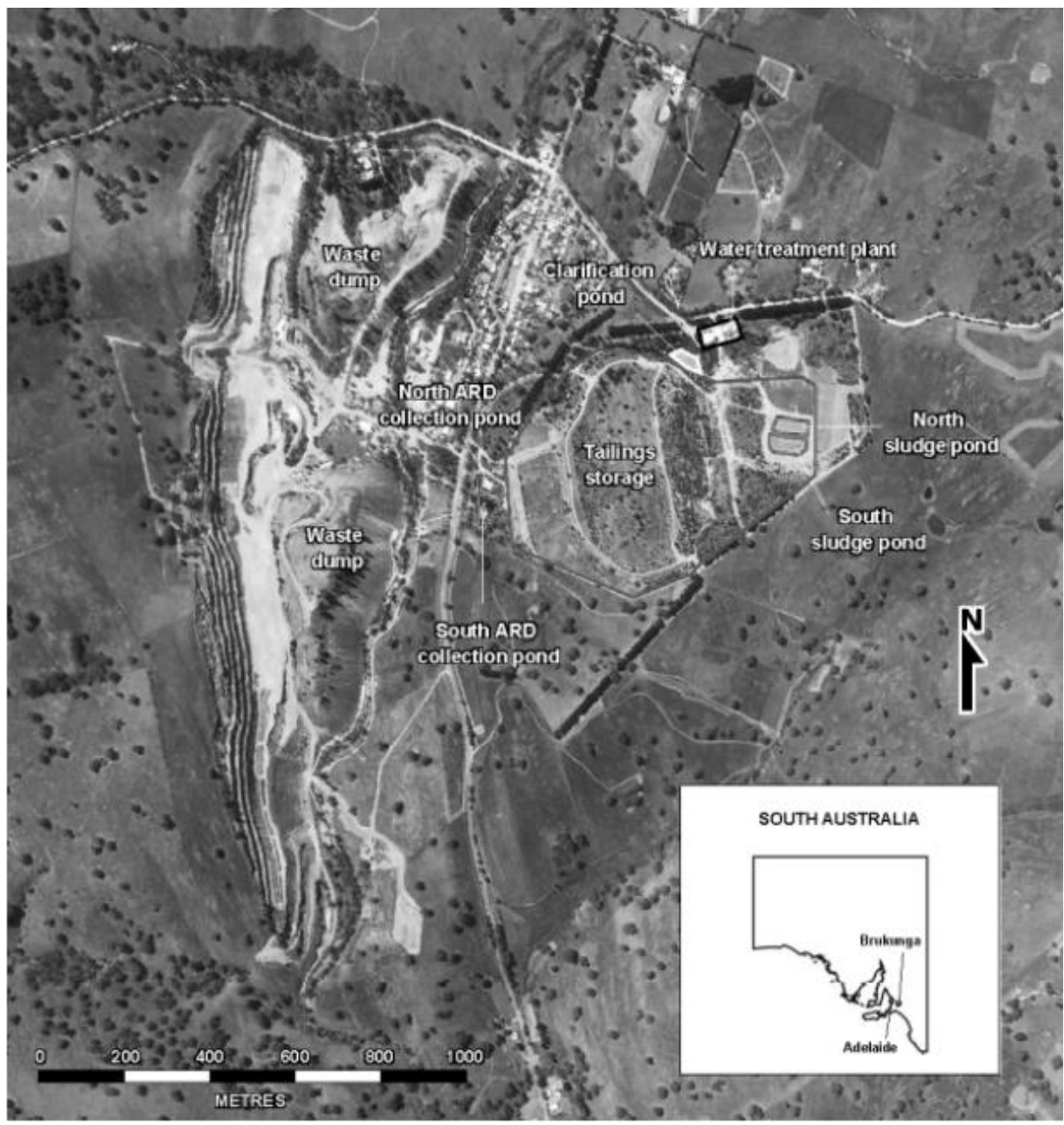

Figure 1 Locality plan (TAG, 2009)

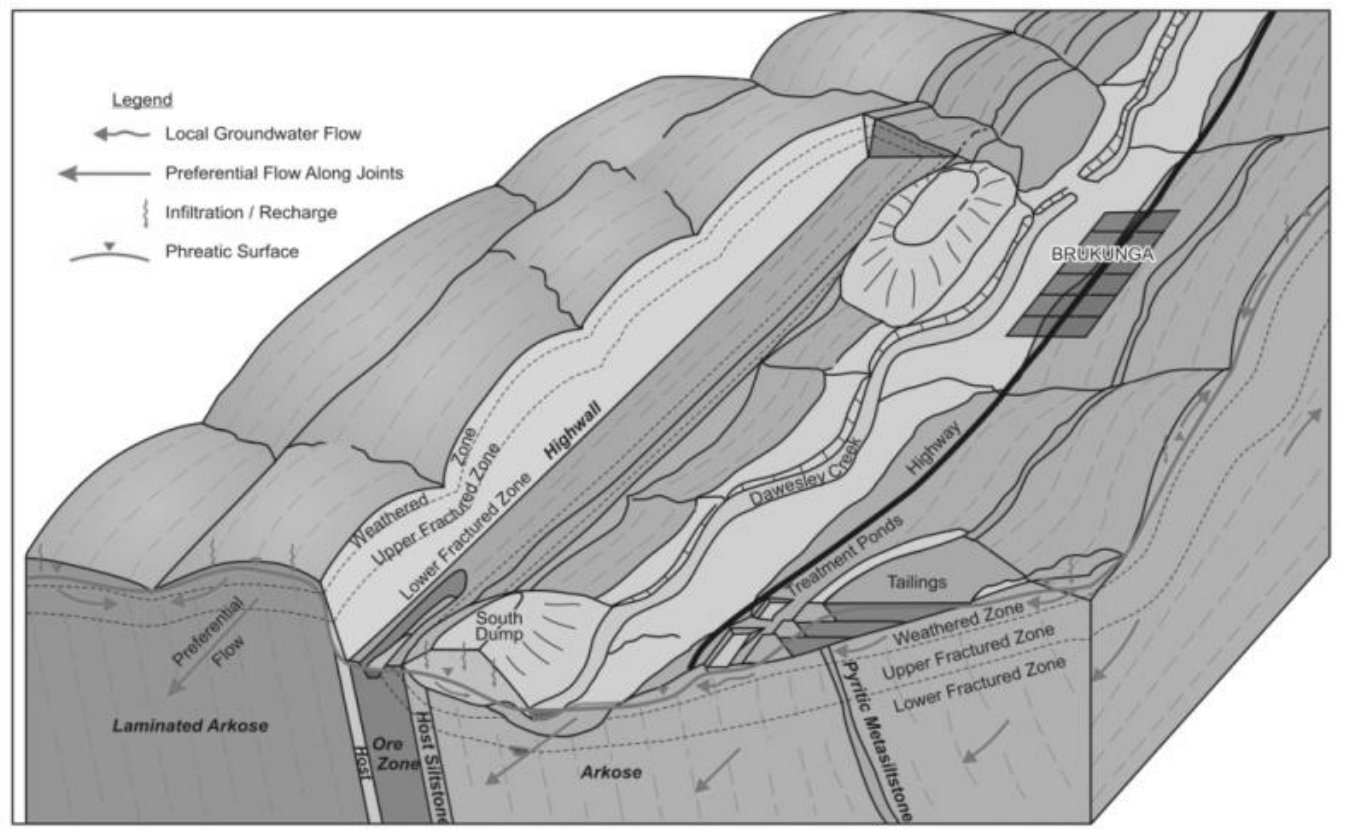

Figure 2 Conceptual geological and hydrogeological model of the Brukunga site (TAG, 2009) 
In general, the site experiences a moisture deficit for the months of September to April, inclusive, and a moisture surplus for May, June, July, and August as shown in Figure 3 (TAG, 2009).

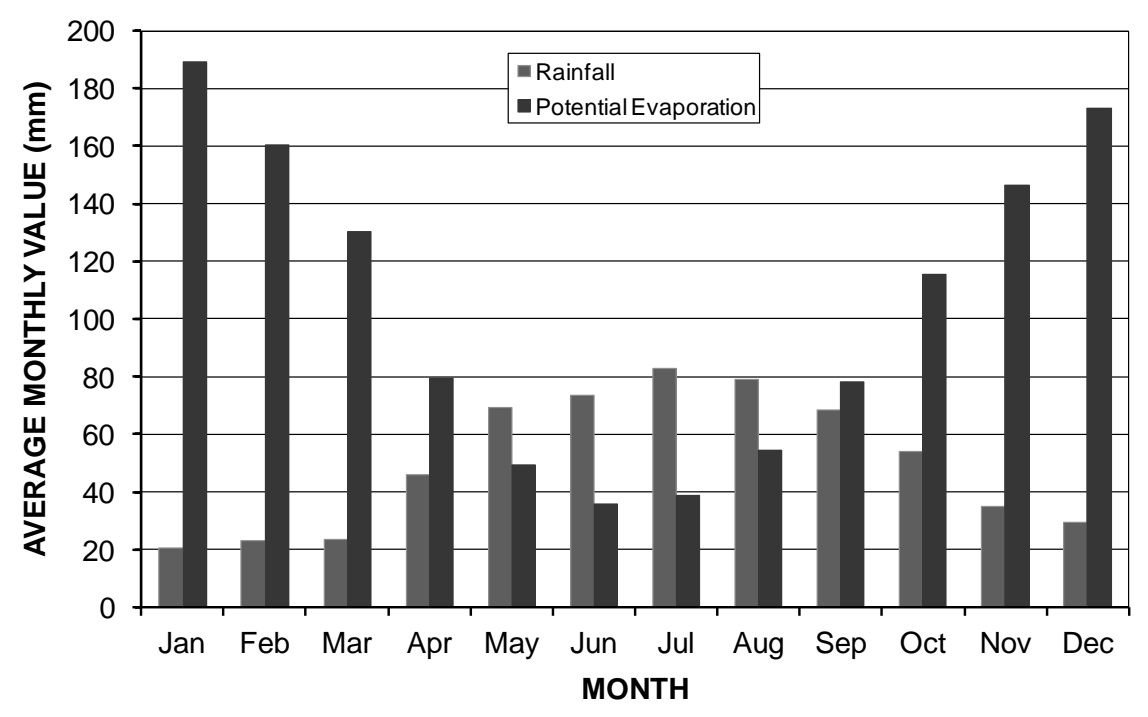

Figure 3 Average monthly rainfall and evaporation

The average daily maximum and minimum temperatures are $20^{\circ} \mathrm{C}$ and $8^{\circ} \mathrm{C}$, respectively.

Geochemical analysis was undertaken to determine the acid forming potential of the rocks and soils contained in the waste dumps with all the samples tested lying within the potentially acid forming (PAF) classifications. The waste rock is estimated to comprise an average of $2 \%$ sulphide sulphur, with the tailings averaging $1.7 \%$ sulphide sulphur, predominantly as pyrrhotite; and the remaining wall rocks within the mined area range from $<2 \%$ sulphide sulphur on the benches and highwall, to up to $13 \%$ sulphide sulphur in the north and south cut areas.

The annual sulphate load from the site is approximately 3,000 t/year (TAG, 2009).

The water quality from different locations within the mine site are summarised in Table 1.

Table 1 Water quality representative of mine sources

\begin{tabular}{lccc}
\hline $\begin{array}{l}\text { Parameter (mg/L) } \\
\text { Except pH }\end{array}$ & Mine Cuts & Tailings & $\begin{array}{c}\text { Waste Dump } \\
\text { R/O and Seep }\end{array}$ \\
\hline $\mathrm{pH}$ & $2.5-3.0$ & 2.3 & $2.5-3.0$ \\
Acidity & $4,000-8,000$ & 7,000 & $4,000-6,000$ \\
$\mathrm{SO} 4$ & $5,000-10,000$ & 8,000 & $6,000-9,000$ \\
$\mathrm{Fe}$ & $1,000-2,500$ & 4,000 & $200-600$ \\
$\mathrm{Al}$ & $400-800$ & 50 & $700-1,000$ \\
$\mathrm{Mg}$ & $200-500$ & 300 & $200-300$ \\
$\mathrm{Mn}$ & $20-40$ & 150 & $30-50$ \\
$\mathrm{Zn}$ & $30-50$ & 15 & $20-50$ \\
\hline
\end{tabular}

The Dawesley Creek catchment upstream from Brukunga consists of over 2,000 ha of sparsely vegetated open pasture. Flow in Dawesley Creek is intermittent with periods of no flow occurring mostly during the months of January and February. Three small creeks (Days Creek, Shepherds North Creek and Shepherds South Creek) flow into the mine site from the west, resulting in their flows becoming contaminated by the mine. 
Average annual discharge for the Dawesley Creek catchment immediately upstream of the Brukunga Mine site was 776 ML between 1994 and 2007, compared with 1,008 ML for the same period downstream of the mine site, indicating that $232 \mathrm{ML}$ was contributed from within the mine site catchments.

\section{Characteristics of waste}

The estimated waste volumes are $4.74 \mathrm{Mm}^{3}$ of waste rock and $2.6 \mathrm{Mm}^{3}$ of tailings (TAG, 2009), comprising silty sand, with gravel and 15 to $30 \%$ cobbles, some clay, and some large size boulders (150 to 1,500 mm).

Field paste testing gave paste $\mathrm{pH}$ values ranging from 2.7 to 3.7 , and the paste electrical conductivity values ranging from 84 to $2,660 \mu \mathrm{S} / \mathrm{cm}$. A single water replacement field density test conducted gave a high dry density of $2.25 \mathrm{t} / \mathrm{m}^{3}$. The average dry density based on 13 tests using a nuclear density gauge was approximately $1.7 \mathrm{t} / \mathrm{m}^{3}$, which is considered representative of the matrix component of the material. The average in situ gravimetric moisture content measured was about $10 \%$. An in situ dry density in the range from 2.2 to $2.3 \mathrm{t} / \mathrm{m}^{3}$ equates to a porosity of approx. 0.2.

A simplified falling head test method involving sequential filling of an excavated pit with water and measuring the drain down, showed the saturated hydraulic conductivity of the top $0.2 \mathrm{~m}$ of North Waste Rock Dump was estimated to be about $1 \times 10^{-6} \mathrm{~m} / \mathrm{s}$.

At the TSF, oxidised tailings extended to depths varying from 0.9 to $1.7 \mathrm{~m}$. These in turn were underlain by laminated un-oxidised tailings interbedded by oxidised tailings to the depth investigated of 3.0 to $3.3 \mathrm{~m}$.

Field paste $\mathrm{pH}$ values for the tailings generally decreased with depth, from 5.8 to 3.2. Field paste electrical conductivity values generally increased with depth, from 40 to $1,100 \mu \mathrm{S} / \mathrm{cm}$. These trends are attributed to the dominance of ongoing net percolation flushing both acidity and salinity into the tailings.

The measured in situ dry density of the tailings ranged from 1.35 to $1.45 \mathrm{t} / \mathrm{m}^{3}$, which equates to a porosity of about 0.45 to 0.55 , assuming a range of specific gravity from 2.7 to 3.0 .

In situ testing of the saturated hydraulic conductivity of the tailings gave values ranging from $1 \times 10^{-5} \mathrm{~m} / \mathrm{s}$ to $1 \times 10^{-6} \mathrm{~m} / \mathrm{s}$ and $5 \times 10^{-5}$ to $1 \times 10^{-7} \mathrm{~m} / \mathrm{s}$ for oxidised and unoxidised tailings, respectively, near the surface. This is an appropriate range for sand to silty-sand tailings.

\section{Co-disposal}

A key component of the conceptual rehabilitation plan for Brukunga is the co-disposal of the various wastes to produce a better grading of material able to be compacted to a significantly higher dry density than the component parts and with improved engineering parameters, most importantly lower permeability. The aims of the co-disposal project were to assess the feasibility of mixing and compacting the waste materials, to determine the density achieved and to assess the impact of saturation on the rate of oxidation.

The geochemical testing indicated that crushed limestone addition of $1.0 \%$ by dry mass would provide sufficient neutralisation capacity to deal with current and pre-saturation sulphuric salts within the waste rock/tailings mixture, with a stoichiometric safety factor of approximately 4 .

The particle size distribution curves for the various mixes are summarised in Figure 4, in which the mixture comprised of waste rock and tailings, in the dry mass ratio 63:37, plus $1 \%$ crushed limestone. This ratio is based on the conservatively estimated volumes of the existing waste rock and tailings. As can be seen, the mixture is somewhat better graded than the sampled waste rock, and much better graded than the narrowlygraded tailings, which facilitates achieving a high compacted dry density.

Laboratory saturated falling head permeability testing of the waste rock, tailings, and co-disposed mixture, each with $1 \%$ crushed limestone added, was carried out by The University of Queensland. Table 2 presents the calculated saturated hydraulic conductivities. This shows a weighted increase in density of the co-disposed waste of $15 \%$ and a halving of the permeability. Results would be expected to be more significant if coarser waste rock was involved.

Two field trials, each measuring about $15 \mathrm{~m}$ long by about $4 \mathrm{~m}$ wide by about $0.5 \mathrm{~m}$ high, were carried out on 3 June 2009 on the Brukunga Mine bench, comprising the compaction of mixed waste using a 10 t, smooth-drum, self-propelled roller (Williams, 2009). The co-disposal trial indicated that a compacted dry 
density of up to $1.85 \mathrm{t} / \mathrm{m}^{3}$ (up to $97 \%$ of laboratory standard maximum dry density (MDD)) is achievable at a moisture content of $16.5 \%$, which is $3.2 \%$ wet of laboratory Standard optimum moisture content (OMC). This corresponds to a calculated degree of saturation of $90 \%$ (assuming a specific gravity of 2.8).

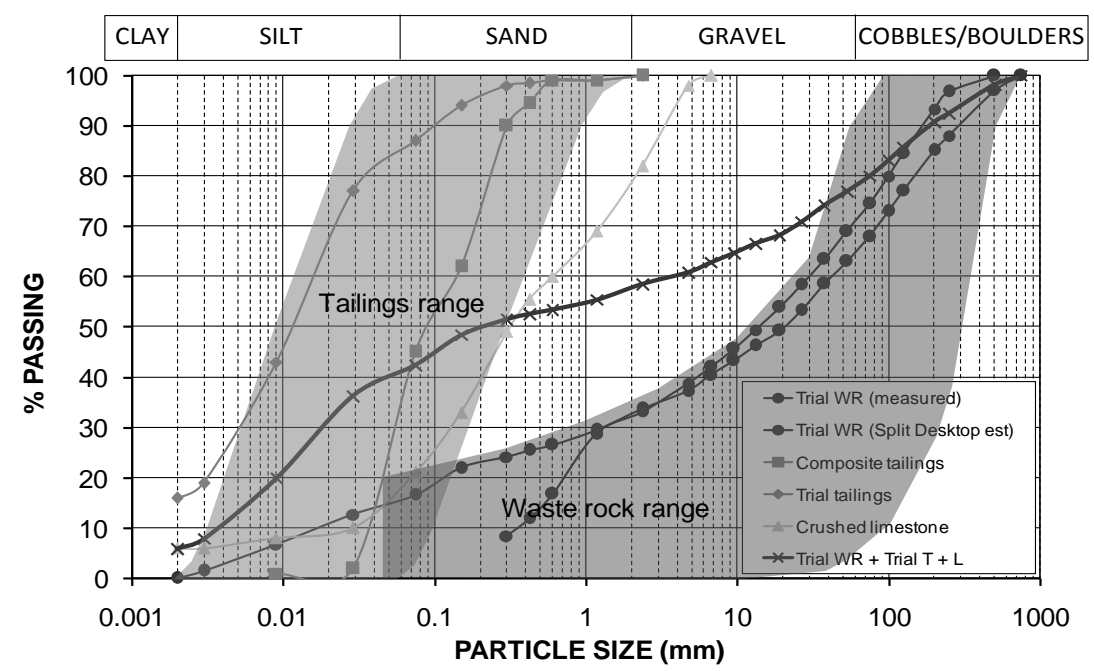

Figure 4 Measured particle size distribution curves for co-disposal trial waste rock, tailings and crushed limestone, and estimated mixture

Table 2 Properties of individual wastes and co-disposed wastes

\begin{tabular}{lccc}
\hline Waste & $\begin{array}{c}\text { Moisture } \\
\text { Content }(\%)\end{array}$ & $\begin{array}{c}\text { Dry Density } \\
\left(\mathbf{t} / \mathbf{m}^{\mathbf{3}}\right)\end{array}$ & $\begin{array}{c}\text { Saturated Hydraulic } \\
\text { Conductivity }(\mathbf{m} / \mathbf{s})\end{array}$ \\
\hline Scalped $(<4.75 \mathrm{~mm})$ trial waste rock & 10.3 & 1.62 & $4.8 \times 10-7$ \\
Trial tailings & 12.8 & 1.43 & $8.2 \times 10-7$ \\
Co-disposed WR:T $=63: 37$ & 14.0 & 1.78 & $3.0 \times 10-7$ \\
\hline
\end{tabular}

The materials used in the field co-disposal trials (re-worked waste rock, surficial tailings excavated from the centre of the TSF, and crushed limestone) are shown in Figure 5.

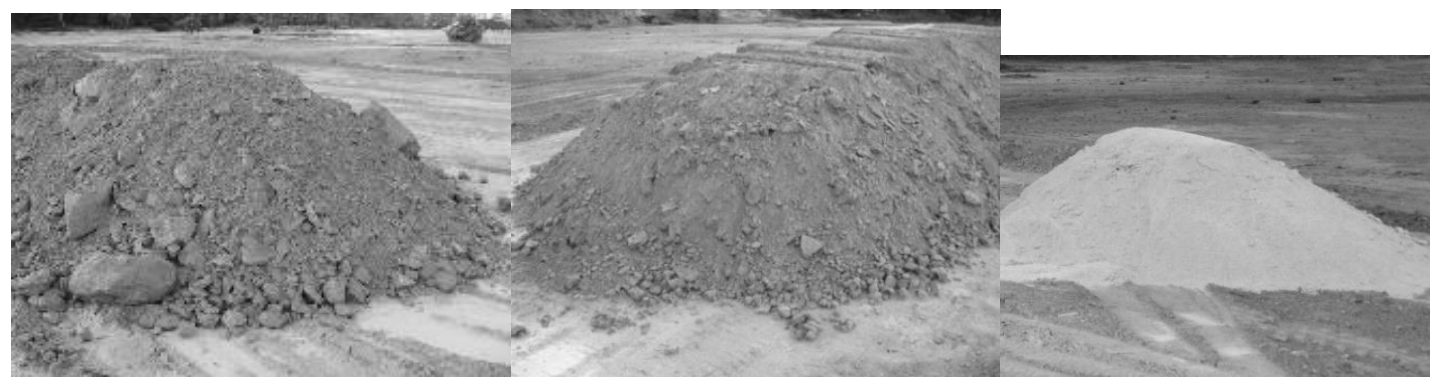

(a) (b) (c)

Figure 5 Materials used in field co-disposal trials; (a) Re-worked waste rock; (b) Surficial tailings; (c) Crushed limestone

The field trials achieved compacted dry densities and degrees of saturation significantly higher than was achieved in the laboratory. At the dry density of up to $1.85 \mathrm{t} / \mathrm{m}^{3}$ (up to $97 \%$ of laboratory standard MDD for the mixture) achieved in the co-disposal field compaction trial at a placed gravimetric moisture content of $16.5 \%$ (3.2\% wet of laboratory standard OMC for the mixture), the degree of saturation of the compacted mixture is up to $90 \%$. Hence, at the as-placed gravimetric moisture content, the compacted waste 
rock/tailings mixture achieved near-saturated conditions. To fully saturate the compacted waste rock/tailings mixture would require only a $3.3 \%$ addition of water on a volume basis.

Due to the higher dry densities achieved in the field, permeability testing gave saturated hydraulic conductivities an order of magnitude lower than was achieved in the laboratory (about $1.0 \times 10^{-8} \mathrm{~m} / \mathrm{s}$ in the field).

Oxidation tests on the compacted materials (Earth Systems, 2008) showed that:

- The low hydraulic conductivity, reasonable air-entry value (AEV), high water storage capacity and relatively small drying/wetting hysteresis of the compacted waste rock/tailings mixture suggest that it would have a high capability to hold water and remain saturated (or tension saturated) between rainfall events.

- The oxidation rate of a compacted co-disposed waste varies approximately linearly with the moisture content of the mixture over a range of moisture contents from 5 (representing desiccated conditions with a degree of saturation of only $24 \%$ ) to $19 \%$ (near-saturated at a degree of saturation of $93 \%$ ), from $1.54 \% / y e a r$ to zero.

- The higher dry density and hence higher degree of saturation achieved in the field for a compacted waste rock/tailings mixture would be expected to lead to lower oxidation rates than those achieved in the laboratory using scalped waste rock, and an oxidation rate of close to zero would be achievable in the field following compaction.

- Full saturation of the compacted waste rock/tailings mixture in the field would ensure an oxidation rate close to zero.

\section{$5 \quad$ Water balance}

To evaluate the potential to maintain saturated conditions in the co-disposed waste placed upstream of the cut-off embankments, water balance modelling was undertaken.

The approach to the modelling was two-fold. Initially, two-dimensional (2-D) saturated-unsaturated seepage modelling was used. Following this, three-dimensional (3-D) saturated-unsaturated flow modelling was used to confirm the 2-D modelling, and provides a more realistic representation of anticipated conditions.

The 3-D model was calibrated to the current condition in order to confirm hydrogeological parameters used. The 3-D flow model was then used to simulate the remediation option. Finally, the 3-D flow model of the remediation was used to simulate solute transport of sulphate and manganese in order to gain some understanding of groundwater impacts due to implementation of the remediation option.

The 2-D modelling was undertaken by Newmans Geotechnique (Newmans, 2009). GHD carried out the 3-D modelling using a MODFLOW / SURFACT model (GHD, 2009a, 2009b) and Golder completed a 3-D model using FEFLOW (Golder Associates, 2009). Particular effort was put into this modelling as it represents the key risk to the project.

\subsection{2-D modelling program}

The 2-D modelling program was carried out using the SEEP/W finite element software program developed by Geo-Slope International Ltd. The steady state models were completed using an assumed net percolation through the proposed soil cover system where the rate of applied surface flux varied according to a percentage of average annual rainfall. The transient model was carried out by applying 100 years of daily net percolation data. The 100 year analyses allowed for a more realistic surface boundary condition in the model; however, due to the very lengthy time required to solve these models, these boundary conditions were only applied to the worst case de-saturation results as computed from the $90+$ steady state cases simulated.

Figure 6 shows a typical cross-section of the conceptual dump face, which includes the co-disposed waste, a mixed clay/rockfill at the surface of the embankment, clean clay and sulphide clay within the embankment, and a toe drain / filter layer at the toe of the embankment. In addition, fractured bedrock and fresh or tight bedrock were modelled as part of the cross-section. 


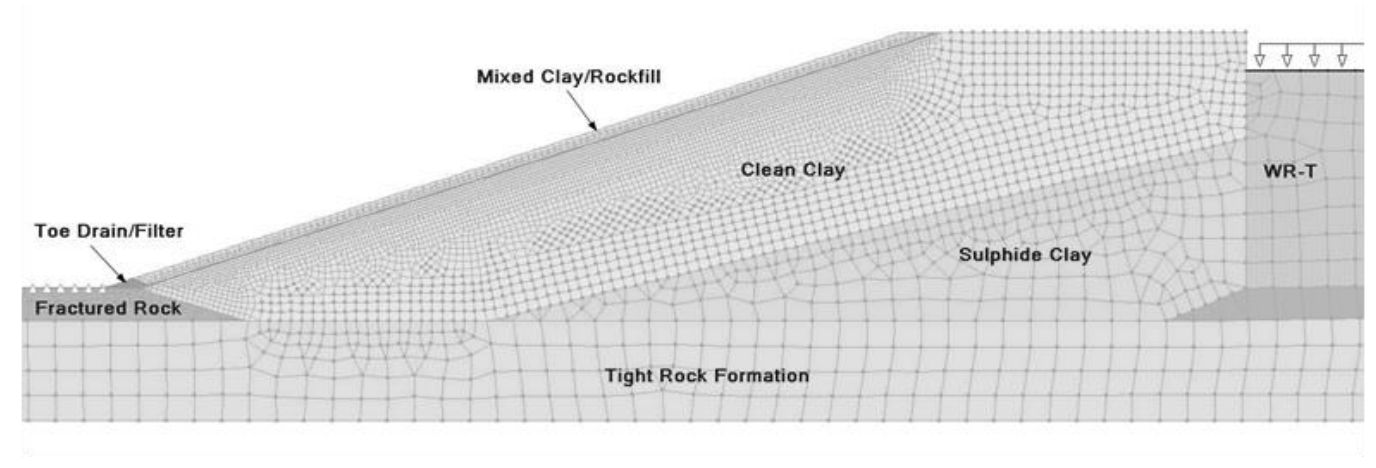

Figure 6 Finite element model of typical embankment cross-section for seepage analysis

Base scenarios were conducted for three net percolation conditions, i.e. 1, 5, and $10 \%$ of the average annual rainfall. Results are presented in Table 3. The total seepage represents the amount of recharge required to maintain the phreatic surface at its computed location within the profile because the models are steady state analyses.

The results of the 2-D numerical modelling showed that predicted seepage for the steady state case was very small and the extent of potential drying very limited, being only 66 to $212 \mathrm{~m}$ from the downstream edge, whereas the waste disposal area extended for up to $2000 \mathrm{~m}$. The 100-year transient models completed for the worst case steady state de-saturation scenarios showed no de-saturation. This is due to the fact that the 100 -year net percolation rate is ten times greater than the lowest assumed steady state net percolation rate.

Table 3 2-D seepage model results showing depth to water table, extent of drying and total seepage for base cases and worst cases analysed

\begin{tabular}{|c|c|c|c|c|c|c|c|}
\hline \multirow{3}{*}{$\begin{array}{c}\text { Analysis } \\
\text { Name }\end{array}$} & \multirow{3}{*}{$\begin{array}{l}\text { Net } \\
\text { Percolation } \\
\text { applied to } \\
\text { WR-T }\end{array}$} & \multirow{2}{*}{\multicolumn{3}{|c|}{$\begin{array}{c}\text { Conductivity Values Used for } \\
\text { WR-T, Clay Core and Fractured } \\
\text { Rock Materials } \\
\text { BC ( Base Case) } \\
\text { H (1/2 order of magnitude higher) } \\
\text { L (1/2 order of magnitude lower) }\end{array}$}} & \multirow{3}{*}{$\begin{array}{l}\text { Max Depth } \\
\text { from Surface } \\
\text { to Water } \\
\text { Table in WR-T } \\
\text { (m) }\end{array}$} & \multirow{3}{*}{$\begin{array}{l}\text { Upstream } \\
\text { Distance of } \\
\text { negative PWP } \\
\text { within WR-T } \\
\text { (m) }\end{array}$} & \multirow{3}{*}{$\begin{array}{c}\text { Seepage } \\
\left(\mathrm{m}^{3} / \mathrm{yr}\right)\end{array}$} \\
\hline & & & & & & & \\
\hline & & WR-T & $\begin{array}{l}\text { Clay } \\
\text { Core }\end{array}$ & $\begin{array}{c}\text { Fractured } \\
\text { Rock }\end{array}$ & & & \\
\hline LSECT1-1 & $1 \%, 6 \mathrm{~mm} / \mathrm{yr}$ & $\mathrm{BC}$ & $\mathrm{BC}$ & $\mathrm{BC}$ & 0.68 & 66 & 1.16 \\
\hline LSECT1-1a & $1 \%, 6 \mathrm{~mm} / \mathrm{yr}$ & BC & $\mathbf{H}$ & BC & 1.45 & 82 & 1.71 \\
\hline LSECT2-1 & $1 \%, 6 \mathrm{~mm} / \mathrm{yr}$ & $\mathrm{BC}$ & $\mathrm{BC}$ & $\mathrm{BC}$ & 1.37 & 160 & 2.33 \\
\hline LSECT2-1a & $1 \%, 6 \mathrm{~mm} / \mathrm{yr}$ & BC & $\mathbf{H}$ & BC & 3.01 & 212 & 5.43 \\
\hline LSECT3-1 & $1 \%, 6 \mathrm{~mm} / \mathrm{yr}$ & $\mathrm{BC}$ & $\mathrm{BC}$ & $\mathrm{BC}$ & 0.90 & 136 & 2.47 \\
\hline LSECT3-1a & $1 \%, 6 \mathrm{~mm} / \mathrm{yr}$ & BC & $\mathbf{H}$ & BC & 3.80 & 187 & 6.74 \\
\hline LSECT4-1 & $1 \%, 6 \mathrm{~mm} / \mathrm{yr}$ & $\mathrm{BC}$ & $\mathrm{BC}$ & $\mathrm{BC}$ & 0.60 & 98 & 2.10 \\
\hline LSECT4-1a & $1 \%, 6 \mathrm{~mm} / \mathrm{yr}$ & BC & $\mathbf{H}$ & BC & $\begin{array}{l}2.50 \\
* \text { Worst cas }\end{array}$ & $\begin{array}{c}182 \\
\text { de-saturation a }\end{array}$ & $\begin{array}{l}4.16 \\
\text { shown in bold }\end{array}$ \\
\hline
\end{tabular}

\subsection{3-D Modelling}

GHD used PERFECT, a one-dimensional cropping and soil moisture balance model to estimate recharge rates and evapotranspiration values for use in the 3-D modelling. PERFECT model outputs were calibrated to gauged stream flow.

Annual average, monthly average, and daily time series outputs from the calibrated PERFECT model showed long-term average annual recharge (1950-2007) is estimated to be $21 \mathrm{~mm} /$ year under pasture and $19 \mathrm{~mm} /$ year under mature trees. Runoff and interflow together are estimated at $37 \mathrm{~mm} /$ year under pasture and $34 \mathrm{~mm} /$ year under mature trees. Thus, the vast majority of the rainfall in the catchment re-enters the atmosphere via evapotranspiration. 
A MODFLOW-SURFACT model was developed by GHD and calibrated to existing groundwater and flow data. Output heads from this steady state simulation were then used as initial heads for a transient model using available climate data from January 1995 to December 2007. This transient model was run using monthly stress periods based on total recharge and evaporation data from the recharge model, and calibrating to observed groundwater level data, using a trial and error approach, by adjustment of the initial storage values and further adjustment of the steady state hydraulic conductivity values.

Following calibration of the model the proposed remediation facilities were added and simulations were carried out in order to predict performance.

Predicted water table elevations remained consistently within the gravel drainage layer with the compacted co-disposed waste remaining saturated throughout the period simulated. Predicted total seepage rates from each area are summarised in Table 4.

\section{Table 4 Predicted seepage rates from co-disposed waste dumps using climate data from February} 1999 to December 2007)

\begin{tabular}{llll}
\hline Dam & Min $\left(\mathbf{m}^{3} / \mathbf{d}\right)$ & Average $\left(\mathbf{m}^{3} / \mathbf{d}\right)$ & $\operatorname{Max}\left(\mathbf{m}^{3} / \mathbf{d}\right)$ \\
\hline Dawesley Creek & 15 & 17 & 21 \\
Days Creek & 6 & 7 & 9 \\
Taylors Creek & 4 & 5 & 6 \\
\hline
\end{tabular}

To place the seepage rates into perspective, the current median flow rate for Dawesley Creek is approximately $960 \mathrm{~m}^{3} / \mathrm{d}$ and the 90 th percentile flow is approximately $34 \mathrm{~m}^{3} / \mathrm{d}$. The predicted seepage is significantly less than the 90th percentile flow and most is likely to remain as sub-surface flow in the alluvium.

\section{Conclusions}

Modelling of the proposed remediation landform and hydrological regime has confirmed that, for this particular site, where foundation conditions and co-disposed waste materials have predicted low permeability, there is sufficient water input, from surface water flows and direct recharge, to maintain saturated conditions within the waste storage. This is the case for even exceptionally dry conditions, without any significant impact to flow down Dawesley Creek.

1. The co-disposal trials confirmed that it is technically and practically feasible to co-dispose and compact the waste rock and tailings to achieve a significant increase in dry density and a much reduced permeability. In addition, sulphide oxidation rates could be reduced to effectively zero if the wastes remain near-saturated.

2. The remediation concept would support a final landform featuring wetlands, meandering streams and native vegetation, to provide an attractive, functional site suitable for various land uses compatible with the remediation aims of the project. Land use for covered saturated waste areas would need to be limited to preclude uses that could impact on saturation of the wastes. This would exclude uses such as forestry and groundwater extraction. Large areas of land exposed by removal of wastes would potentially suit a range of land uses ranging from forestry, parkland, to commercial or residential development.

Figure 7 shows the lowest groundwater levels predicted for a remediation storage area, noting that this remains in the gravel recharge zone.

The Brukunga Mine Site Remediation Project has demonstrated that, with the right conditions and careful design, it is possible to create saturated waste dumps that are effectively water covered even in relatively dry climates. This type of approach is considered to have the potential to allow a walk away closure scenario at Brukunga as remediation of an existing site, but would also be appropriate for disposal of PAF wastes at active mines, even in relatively arid climates. 
Dawesley Creek Remediation Dam Long Section (Approx N - S) After 35 Years (420 Months)

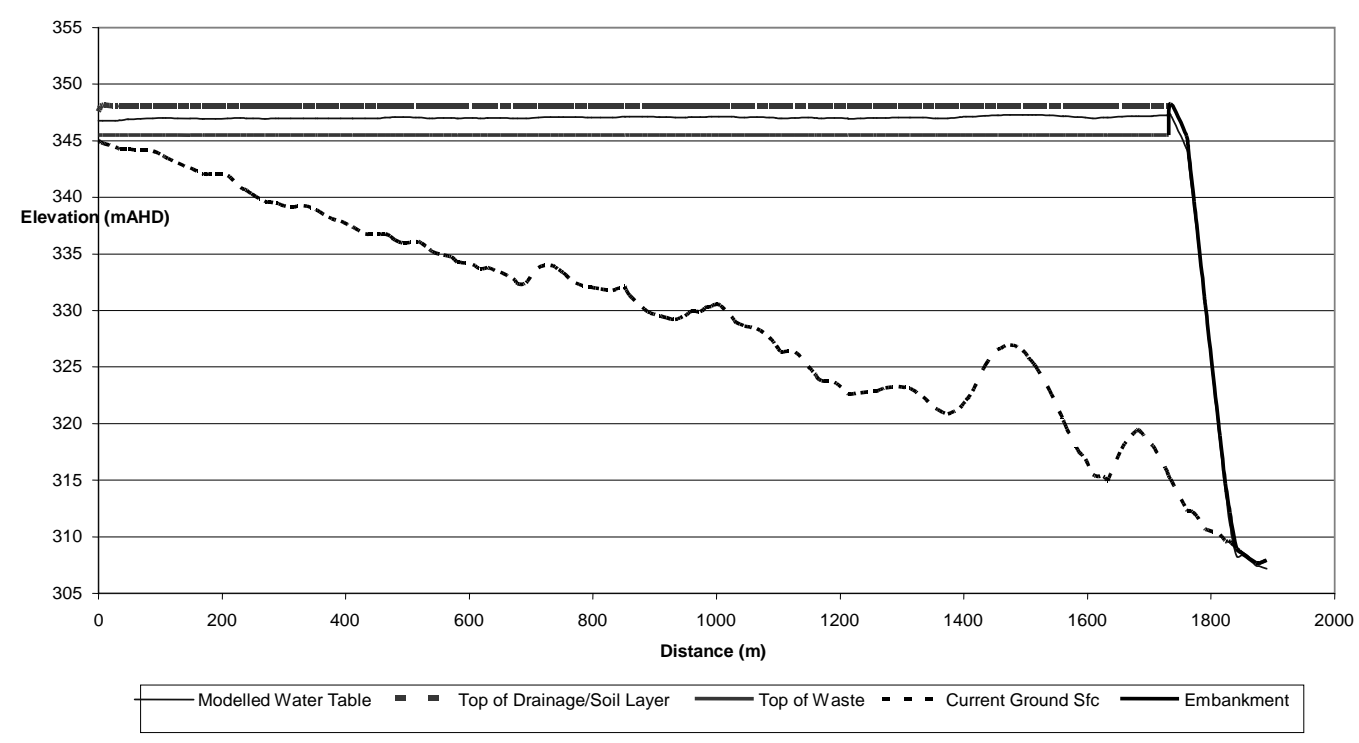

Figure 7 Cross-section of co-disposed waste storage showing lowest modelled groundwater levels, still within the recharge zone and above the waste material

\section{Acknowledgements}

The authors acknowledge PIRSA for permission to publish this paper.

\section{References}

Earth Systems (2008) Waste rock test work at the Brukunga Mine Site, South Australia, Summary of November 2008 to August 2009. Report prepared for Primary Industries and Resources South Australia (PIRSA).

GHD (2009a) Site Water Balance Model, 30 September 2009. Report prepared for Primary Industries and Resources South Australia (PIRSA).

GHD (2009b) Predicted Post-Remediation Water Balance Model, September 2009. Report prepared for Primary Industries and Resources South Australia (PIRSA).

Golder Associates (2009) Report prepared for Primary Industries and Resources South Australia (PIRSA), ThreeDimensional Regional Groundwater Flow Modelling (FEFLOW) - Brukunga Mine Rehabilitation Program, October 2009.

McCleary, M.B. (2009) Striving for "walk away" - focussing an expert group on the "holy grail" of mine closure, Proceedings of the Fourth International Conference on Mine Closure 2009, A. Fourie and M. Tibbett (eds), 9-11 September 2011, Australian Centre of Geomechanics, Perth, Western Australia, pp. 359-373.

Newmans (2009) Report on Seepage Analysis, Newmans Geotechnique, Report prepared for Primary Industries and Resources South Australia (PIRSA).

Scott, P.A., Taylor, J., Grindley, P., McLeary, M., Brett, D., Williams, D. and O'Kane, M. (2011) Case Study for Avoiding Treatment in Perpetuity - The Brukunga Pyrite Mine Example, Mine Closure 2011, Calgary, in press.

SKM (2009) Geotechnical, Geochemical and Hydrogeological Drilling Investigations (BR01-02), PHASE 1-5, DRAFT, 20 August 2009.

TAG (2008) Technical Advisory Group. Final Report on the Development and Assessment of Remediation Options for the Brukunga Remediation Project, Prepared for the Department of Primary Industries and Resources South Australia (PIRSA) by Technical Advisory Group (TAG), 31 October 2008, unpublished.

TAG (2009) Technical Advisory Group. Phase 2 Report - Validating the technical feasibility of a saturated waste remediation option for the Brukunga Remediation Project, Prepared for the Department of Primary Industries and Resources South Australia (PIRSA) by Technical Advisory Group (TAG), October 2009, unpublished.

Williams, D.J. (2009) Report on Co-Disposal Trials. Prepared for the Department of Primary Industries and Resources South Australia (PIRSA), 11 September 2009. 